\title{
Ion Exchange Dish as a Tool for Cell Separation Based on Cell Surface Charge
}

\author{
Shoshi Inooka \\ Department of Animal Science, Faculty of Agriculture, Tohoku University, 1-1 \\ Tsutsumidori Amamiya-Machi, Sendai 980, Japan
}

\begin{abstract}
Methods of animal cell separation were studied based on cell surface charge. An ion exchange dish was devised by the author by coupling DEAE- or CM-Sephadex beads with polyacrylamide gel. Binding was shown of various animal cells to DEAE-Sephadex beads in the devised dish. The dissociation of bound mouse spleen lymphocytes was then examined using various reagents. More than $60 \%$ of adsorbed cells were dissociated by addition of a mixed solution of sodium citrate and Tween 80 with no detectable decrease in cell viability. The actual recovery of bound cells was also tested, and the stepflow method for elution was useful with solution containing sodium citrate, Tween 80 , polybrene and EDTA at various concentrations of $\mathrm{NaCl}$. The possibility of cell separation based on differences in cell surface charges was demonstrated in some cells.
\end{abstract}

Methods of cell separation based on such difference in physical properties as cell size, cell volume, cell density, adherent activity to solid substrates, e.g. antibody-bound non-ionic supports $(1,3,8,11,12)$ and cell surface charge have been reported (2). Cell surface charges as suggested by the experiment on cell electrophoresis (9) may be useful in cell separation, though practical and convenient methods utilizing differences in cell surface charge have not been well established.

Ion exchangers containing side groups, e.g. diethylaminoethyl (DEAE) and carboxymethyl $(\mathrm{CM})$, are naturally considered to be materials for separation based on the cell surface charge. However, useful methods utilizing this kind of material have not been developed. The ionic adsorption of cells to DEAE-Sephadex beads has been demonstrated $(5,6)$. However, a difficulty exists in detouching bound cells from the beads maintaining viability. The use of an ion exchange dish made by coupling ion exchange beads with polyacrylamide gel solves the problem. By the step-flow of the solution containing sodium citrate, Tween 80, polybrene and EDTA through the dish bound cells were dissociated from the beads without a decrease in cell viability. The results suggest that the ion exchange dish is useful for separating cells based on the difference in charges on the cell surface.

\section{MATERIALS AND METHODS}

Preparation of the ion exchange dish. The coupling procedures were: $2 \mathrm{ml}$ of $60 \%$ acrylamide solution containing $0.4 \% \mathrm{~N}^{\prime}, \mathrm{N}^{\prime}$-methylene-bisacrylamide, $0.1 \mathrm{ml}$ of $\mathrm{N}, \mathrm{N}, \mathrm{N}^{\prime}, \mathrm{N}^{\prime}-$ tetramethylethylenediamine and $5 \mathrm{ml}$ of $1 \%\left(\mathrm{NH}_{4}\right) \mathrm{SO}_{2}$ were mixed and poured into a $90 \mathrm{~mm}$ 
diameter plastic Petri dish. DEAE-(CM-) Sephadex beads $(8 \mathrm{ml}$ of a $0.25 \%$ suspension in water) were then layered over the gel solution before polymerization. After polymerization was completed, the remaining solution was decanted and the dish was washed with water twice to remove excess beads, then it was stored at $4^{\circ} \mathrm{C}$ until use.

Cell preparation. Erythrocytes were prepared from the fresh whole blood of sheep and fowl. Leucocytes of fowl were also prepared from the buffy coat of fresh whole blood with Alsvers' solution. Lymphocytes from the spleen of mouse and fowl, and from the bursa of fabricius and the thymus of chick were prepared by mincing each organ. Macrophages were prepared from the peritoneal fluid of DD mice by washing with saline. Ehrlich tumor cells were maintained in the form of ascites with DD mice. BHK cells, PS cells and L cells grown in Eagles MEM supplemented with $10 \%$ serum were dispersed in $2 \%$ EDTA. These cells were washed twice with phosphate buffered saline, then washed with $0.15 \mathrm{M} \mathrm{NaCl}$ in $0.01 \mathrm{M}$ sodium phosphate, $\mathrm{pH}$ 7.1 .In the cell dissociation experiments the lymphocytes of mouse spleen were used. Also, the lymphocytes of mouse and fowl, the macrophages of mouse and the erythrocytes of fowl were used in the cell elution experiments.

Cell binding. An $8 \mathrm{ml}$ suspension of each cell type (containing $8 \times 10^{6}$ total cells in $0.15 \mathrm{M}$ $\mathrm{NaCl}$ ) was pipetted gently onto the dishes and allowed to stand at $20^{\circ} \mathrm{C}$ for $90 \mathrm{sec}$. The aqueous layer containing unattached cells was decanted and the dish was washed twice with 0.15 $\mathrm{M} \mathrm{NaCl}$ to remove loose cells. Bound cells were observed under a microscope and the total cell number bound per bead was counted. The degree of binding are: $H \sim H$ over 50 cells; + between $50-10$ cells; - below 10 cells per bead.

Materials tested for cell dissociation and elution. Materials were tested on their ability to dissociate cells from the ion exchange dish. Sodium chloride, ammonium sulfate, acetic acid, glycine, sodium citrate, lithium sulfate, sodium sulfate, dioctyl sodium-sulfosuccinate, sodium deoxycholate, sodium lauryl sulfate, Triton X-100, Tween 80 , benzethonium chloride, heparin, polybrene, protamine sulfate and dextran sulfate were tested. Mixtures of trypsin and Triton X-100, Tween 80 and trypsin, trypsin and EDTA, sodium citrate and Triton X-100, sodium citrate and Tween 80 , sodium citrate and EDTA, heparin and Triton X-100, heparin and Tween 80, heparin and EDTA were also examined.

In the cell elution experiments, the solution of sodium citrate, Tween 80, EDTA and polybrene in 0.10 (osmotic pressure modulated by sucrose), $0.15,0.20,0.25,0.30$ and $1.50 \mathrm{M}$ $\mathrm{NaCl}$ (pH 6.7) were used.

Cell dissociation. To test the effect of the various reagents on cell dissociation lymphocytes prepared from mouse spleen were washed twice with phosphate buffered saline. To test the effect of a single reagent, cells were bound to the DEAE-Sephadex beads in a $0.15 \mathrm{M} \mathrm{NaCl}$ solution as described above. Recovery was made with $0.15 \mathrm{M} \mathrm{NaCl}$ containing the reagent to be tested. To test the effect of coupled reagents, cells were bound to beads in a $0.05 \mathrm{M}$ $\mathrm{NaCl}$ solution (osmotic pressure modulated by sucrose) and dissociation was tested in $0.30 \mathrm{M}$ $\mathrm{NaCl}$ solution. After unbound cells had been removed, the solution containing the reagents was pipetted gently onto the dishes. The whole was allowed to stand at $20^{\circ} \mathrm{C}$ for 5 minutes; then after vigorously shaking the dish, the number of loose cells was counted under a microscope. Results of cell dissociation were calculated as follows:

Number of dissociated cells due to treatment with reagents Number of bound cells before treatment with reagents $\times 100$

Rates of dissociation are: $\#$ (over $60 \%$ ), + (between 60 and $40 \%$ ), + (between 40 and $30 \%$ ), and - (under $30 \%$ ).

Elution of bound cells. The DEAE-Sephadex ion exchange dishes were twice washed with 
$0.05 \mathrm{M} \mathrm{NaCl}$ as described above. The washed cells were bound to the DEAE-Sephadex beads by an addition of $8 \mathrm{ml}$ of the cell suspension $\left(10^{6}-10^{7} \mathrm{cells} / \mathrm{ml}\right.$ of $\left.0.05 \mathrm{M} \mathrm{NaCl}\right)$ after which the dishes were kept at $20^{\circ} \mathrm{C}$ for $90 \mathrm{sec}$. Elution of bound cells after the removal of unbound cells was carried out by the step-flow of $8 \mathrm{ml}$ of a solution composed of sodium citrate $(2 \%)$, Tween $80(0.001 \%)$, EDTA $(2.0 \%)$ and polybrene $(0.01 \%)$ in solutions each containing 0.10 , $0.15,0.20,0.25,0.30$ and $1.50 \mathrm{M} \mathrm{NaCl}$, Each flow was carried out at $20^{\circ} \mathrm{C}$ for 5 minutes, and each eluate was collected. The total number of cells eluted was counted with a hemacytometer and cell viability was judged from the results of trypan blue elution tests.

\section{RESULTS}

Cell binding. The adsorption ability of the ion exchange dishes was tested to determine whether the DEAE- or CM- ion exchange group prepared using polyacrylamide gel as the coupling material could best adsorp cells. Results are summarized in Table 1. The data show that all the cells tested bound to the dish with DEAE-Sephadex beads, but not to the dish of CM-Sephadex beads and the polyacrylamide gel layer except for erythrocytes. As shown in a previous paper (5), the binding of cells reached a maximum within $90 \mathrm{sec}$. There appears to be little difference in behavior and in the number of cells between the exchanger dish and the tube which has been previously described (5). This observation shows that coupling is carried out with no formation of a new ion exchange group and with no destruction of the function of the original ion exchange group of beads.

Effect of several reagents on cell dissociation. To dissociate bound cells an experiment was performed using several reagents which were expected to weaken the bonds between the cells and the ion exchange group in the dish. Table 2 shows that the systems of sodium chloride $(18 \%)$, sodium citrate ( 2 or $20 \%$ ), lithium sulfate $(0.1 \%)$, Tween $80(0.001 \%)$ and heparin $(5 \%)$, dissociated about $30-40 \%$ of the adsorbed cells. With dioctylsodium sulfosuccinate, sodium lauryl sulfate, Tween 80 $(0.01 \%)$ and benzethonium chloride, even higher rates of dissociation occured. The

TABLE 1. Adsorption of SOME Kinds of animal Cells to DEAE-SePhadeX BEADS IN ION EXCHANGE DISHES

\begin{tabular}{|c|c|c|}
\hline Cells tested & DEAE-Sephadex & CM-Sephadex \\
\hline Sheep erythrocytes & H & + \\
\hline Fowl erythrocytes & Ht & + \\
\hline Fowl leucocytes & $H$ & - \\
\hline Fowl spleen lymphocytes & $H$ & - \\
\hline Mouse spleen lymphocytes & H & - \\
\hline Ehrlich ascites cells & H: & $\ldots$ \\
\hline Mouse macrophages & H & - \\
\hline BHK cells & H & - \\
\hline PS cells & H & - \\
\hline $\mathrm{L}$ cells & + & - \\
\hline
\end{tabular}

Washed animal cells were suspended in $0.15 \mathrm{M} \mathrm{NaCl}$ solution, $\mathrm{pH}$. 7.1. Cell suspensions were poured into dishes which had been coupled with DEAE- or CM-Sephadex beads. The samples were kept for $90 \mathrm{sec}$ at $20^{\circ} \mathrm{C}$, then after washing off unadsorbed cells the number of cells adsorbed was counted under a microscope. The degree of cell binding is: HH H (over 50 cells), + (between of 10 and 50 cells), and - (below 10 cells) per bead. 


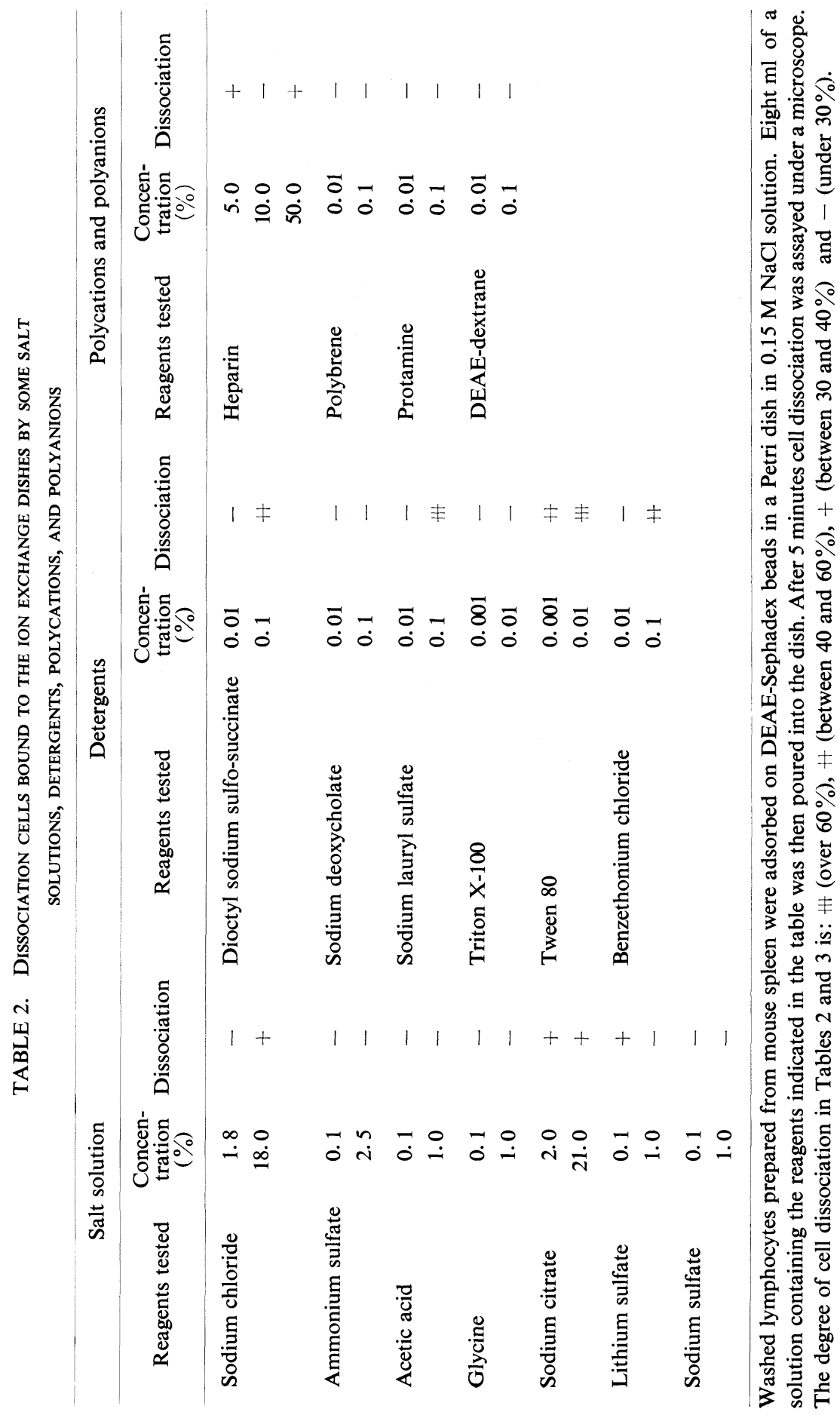


TABLE 3. DISSOCIATION OF BOUND CELLS BY COUPLED REAGENTS

\begin{tabular}{|c|c|c|}
\hline Solution & Mixture & Dissociation \\
\hline Trypsin $(0.2 \%)$ & $\begin{array}{l}\text { Triton X-100 }(0.001 \%) \\
\text { Tween } 80(0.001 \%) \\
\text { EDTA }(2.0 \%)\end{array}$ & $\begin{array}{l}H \\
H \\
H\end{array}$ \\
\hline Sodium citrate $(2 \%)$ & $\begin{array}{l}\text { Triton X-100 }(0.001 \%) \\
\text { Tween } 80(0.001 \%) \\
\text { EDTA }(2.0 \%)\end{array}$ & $\begin{array}{l}H \\
H \\
H\end{array}$ \\
\hline Heparin $(5 \%)$ & $\begin{array}{l}\text { Triton X-100 }(0.001 \%) \\
\text { Tween } 80(0.001 \%) \\
\text { EDTA }(2.0 \%)\end{array}$ & $\begin{array}{l}+ \\
- \\
-\end{array}$ \\
\hline
\end{tabular}

Washed lymphocytes prepared from mouse spleen were adsorbed on the dish in $0.05 \mathrm{M} \mathrm{NaCl}$ solution. Eight $\mathrm{ml}$ of a mixture of the reagents in $0.30 \mathrm{M} \mathrm{NaCl}$ solution was poured into the dish. After 5 minutes cell dissociation was assayed under a microscope.

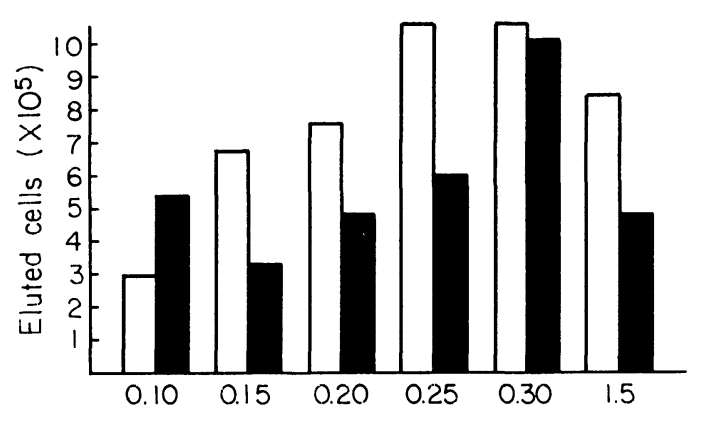

a

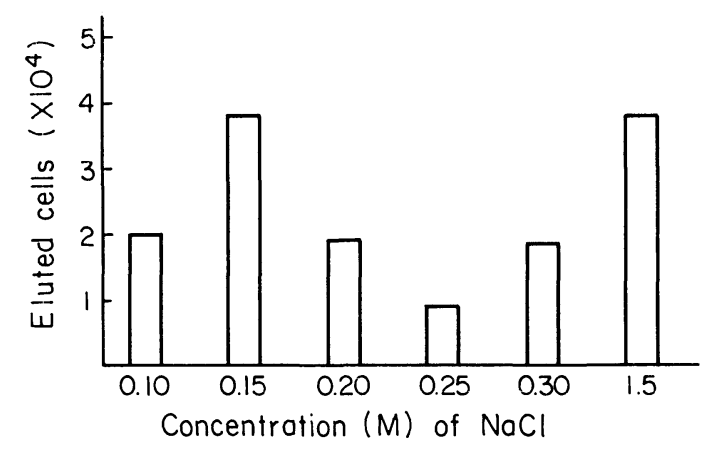

b

Fig. 1. Elution of bound cells by the step flow of a solution. Washed cells were bound to DEAESephadex beads in $0.05 \mathrm{M} \mathrm{NaCl}$ solution. Eight $\mathrm{ml}$ of the solution mixture of Tween $80(0.001 \%)$, sodium citrate $(2 \%)$, EDTA $(2 \%)$ and polybrene $(0.01 \%)$ in $0.10,0.15,0.20,0.25,0.30$ and $1.50 \mathrm{M}$ $\mathrm{NaCl}$ solution, $\mathrm{pH}$ 6.7, was poured into the dish, at 5 minute sintervals. The total number of cells in each eluate was counted. a) mouse spleen lymphocytes (open column) and fowl erythrocytes (solid column) b) mouse macrophages. 


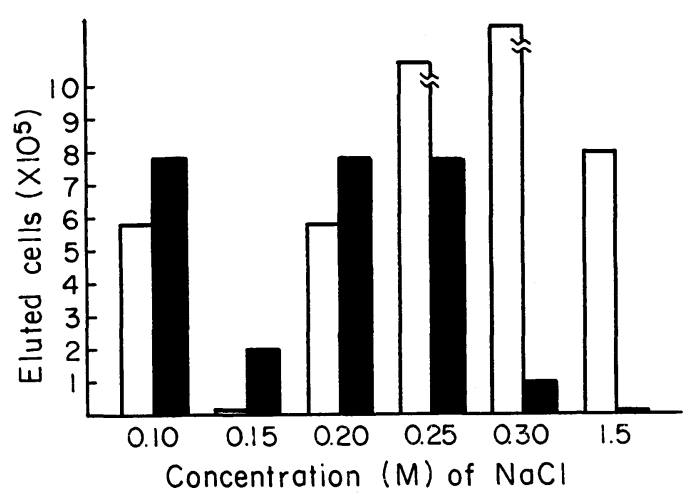

Fig. 2. Elution of bound lymphocytes of bursa and thymus by the step-flow of a solution. Washed lymphocytes of the brusa and the thymus were bound to DEAE-Sephadex beads in $0.05 \mathrm{M}$ $\mathrm{NaCl}$ solution. Eight $\mathrm{ml}$ of the elution was poured into the dish at 5 minutes intervals. Fractions of the same type were pooled and the total number of cells was counted. Open column, Thymus cells; Solid colum, Brusa cells.

latter results may be due to the destruction of adsorbed cells because these reagents were cytotoxic at the concentration tested.

Effects of coupled reagents on cell dissociation. To obtain a higher yield than that for dissociation with single reagents, the effects of coupled reagents were tested. Results are given in Table 3. In the mixture systems of trypsin and Triton X-100, and of sodium citrate and Tween 80 , more than $60 \%$ of the bound cells were dissociated from the beads. In contrast, incubation with the other coupled reagents resulted in cell dissociation of less than $60 \%$.

Elution of bound cells. Since results of the dissociation of lymphocytes from the ion exchange dish with the coupled reagents were good, the elution of bound lyphocytes, erythrocytes and macrophages from the dishes was tested using a flow of $\mathrm{NaCl}$ solution at various concentration containing polybrene, EDTA, sodium citrate and Tween 80. Polybrene was added to prevent readsorption on the DEAE-Sephadex beads once cells were loosened. EDTA was added to promote the loosening of cells. Results are shown in Fig. 1. Mouse spleen lymphocytes and fowl erythrocytes elutions were dependent on the concentration of $\mathrm{NaCl}$. The recovery of mouse spleen lymphocytes (Fig. 1a) shows a peak at $0.30 \mathrm{M} \mathrm{NaCl}$ as does that of fowl erythrocytes (Fig. 1a). Macrophages (Fig. 1b) were eluted mainly with $0.15 \mathrm{M}$ and $1.5 \mathrm{M} \mathrm{NaCl}$ solutions. Viability of the eluted cells in Fig. 1a-1c was more than $90 \%$ in all the fractions collected, based on results of the trypan blue elution test. Total cell recovery calculated from the eluted cells was about $70 \%$ of the total bound cells (Fig. 3).

To test the possibility of cell separation, elution patterns for the lymphocytes of the brusa and the thymus were determined. Lymphocytes of the brusa were eluted mostly in flowing $\mathrm{NaCl}$ solutions with concentrations lower than $0.25 \mathrm{M}$. In cotrast, thymus cells were eluted mainly in flowing $\mathrm{NaCl}$ solutions with concentrations higher than $0.25 \mathrm{M}$ (Fig. 2).

\section{DISCUSSION}

The usefulness of the ion exchange dish as a tool for the separation and manipula- 


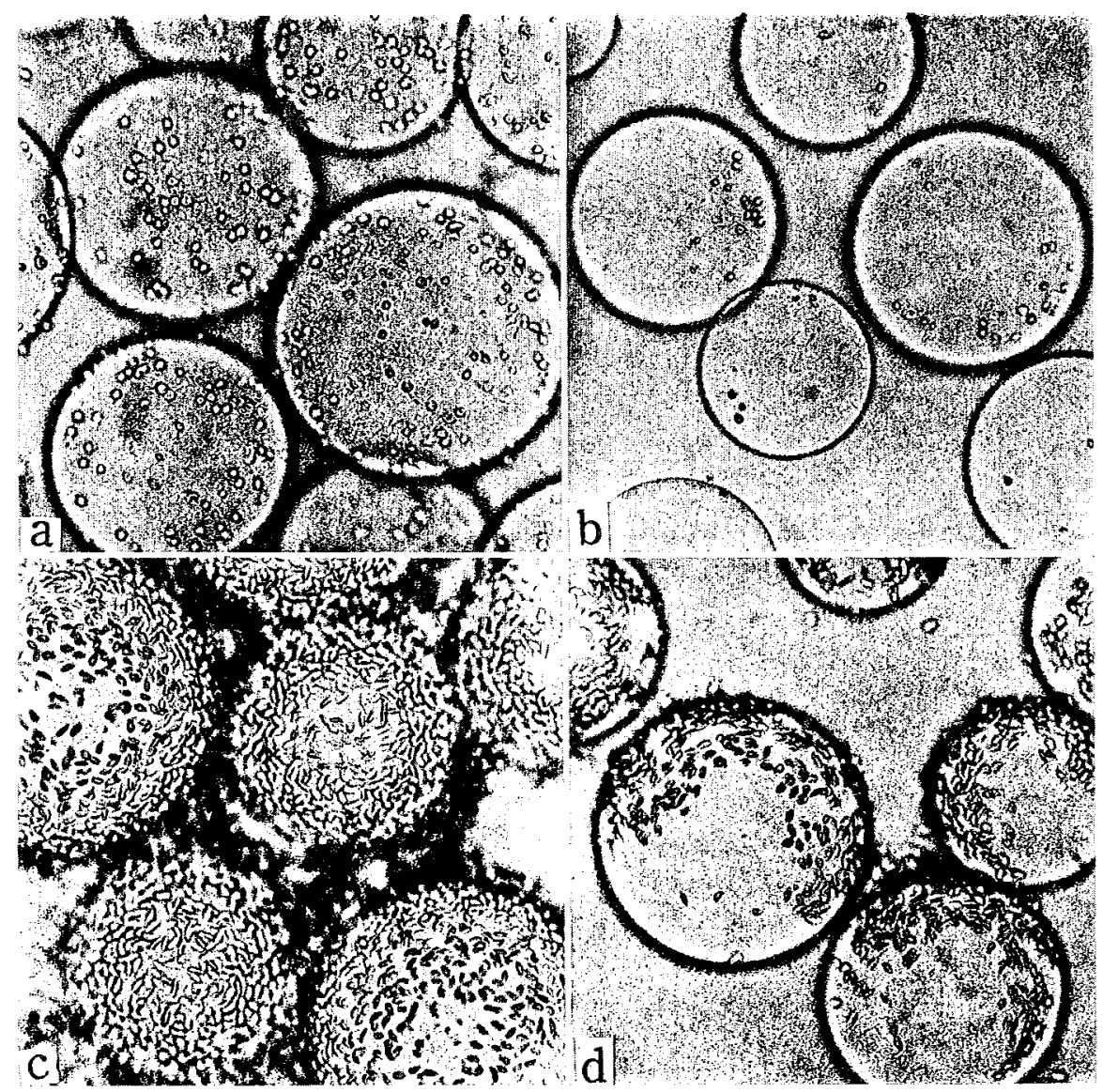

Fig. 3. Photo micrographs of the surface of the ion exchange dishes in the step-flow of a solution. Large particles are DEAES-ephadex beads and small particles are cells bound to the beads. a) dishwith adsorbed mouse macrophages in $0.05 \mathrm{M} \mathrm{NaCl}$, b) dish with adsorbed mouse macrophages in $0.05 \mathrm{M} \mathrm{NaCl}$, which had then been washed with $1.5 \mathrm{M} \mathrm{NaCl}$. c) dish with adsorbed fowl erythrocytes in $0.05 \mathrm{M} \mathrm{NaCl}$. d) dish with adsorbed erythrocytes in $0.05 \mathrm{M} \mathrm{NaCl}$, which had then been washed with $1.5 \mathrm{M} \mathrm{NaCl} . \times 100$

tion of cells, based on cell surface charges and methods of cell recovery from the support, was demonstrated.

The use of beads on Petri dishes has several advantages over columns:

1) The time for adsorption and for the removal of cells is less.

2) Sterile handling is possible.

3) The attachment to and the removal of the cells from the beads can be directly observed.

These are obviously valuable for cell yields and maintenance.

Several materials such as agarose, collagen and gelatin can be used in procedures for coupling the beads with the dishes. Polyacrylamide gel was used in the present experiments as a coupling reagent to prepare the ion exchange dishes. Characteristics of the ion exchange dishes were studied using various cells. The binding of cells to DEAE-Sephadex beads occurs within $90 \mathrm{sec}$ at $20^{\circ} \mathrm{C}$, and within the time the binding 
of cells to polyacrylamide gel or CM-Sephadex beads do not occurs. The observed adsorption was similar to results described previously (6). This suggests that the ion exchange support is useful for cell-handling. However, it is desirable to examine whether the use of DEAE-Sephadex in various kinds of ion exchangers and whether the use of polyacrylamide gel in various coupling materials are best.

Previous attempts to recover cells by elution from the resin with a salt solution produced very poor results, because a high concentration of salt was required. Theoretically it may be possible to separate cells from the support as follows:

1) by destroying the support itself or the materials coating the support

2) by a disappearance of the charges or materials on the cell surface

3) by varying or substituting the binding charge between the DEAE-ion exchange group and the cells

Scholssman et al. (10) tried dextranase in the separation of immunocytes from the antigen coat Sepharose. They reported a high yield of cells obtained over a long treatment period with the enzyme. Kedar (7) also was successful in separating immunocytes from an erythrocyte coated support by lysis of the erythrocytes. But recovery of the cells by digesting the substances on the cell surface was not very successful because cell recovery was not observed for the majority of cells when bound cells were treated in solutions of trypsin, collagenase and other enzymes. I believe the binding between the ion exchange groups of the resin and the cell surface is very strong and complex. However, I observed that Ehrlich cells bound with DEAE-Sephadex beads were easily recovered with trypsin (unpublished data). This phenomenon has not yet been investigated, but it suggests that special cells may be recovered by using special enzymes or reagents. It was also difficult to recover cells by substituting the charge of the binding with salts as described above. A test of various reagents demonstrated that a solution of a mixture of sodium citrate and Tween 80 was best for dissociating cells without a decrease in cell viability. In the elution experiments with lymphocytes of brusa and thymus, however, a little difference in the $\mathrm{NaCl}$ concentration was needed for elution (Fig. 2). The elution patterns from the ion exchange dishes may have some correlation with the actual net charge of the lymphocytes of the brusa and thymus cells, because the elution behavior of both paralleled the electrophoretic mobility of each cell (4). The ion exchange dish should be a useful method for cell separation and manipulation. Application methods are being investigated.

Acknowledgments. Thanks are due to Dr. M. Yoshida for his discussion and reading of the manuscript, and to the Eiken Kizai Co., Tokyo, for the preparation of the ion exchange dishes.

\section{REFERENCES}

1. Chipowsky, S., Y.C. Lee and S. Roseman. Adhesion of cultured fibroblasts to insoluble analoguse of cell surface carbohydrates. Proc. Nat. Acad. Sci. USA 70, 2309-2312, 1973

2. CutTs, J.H. Cell separation methods in hematology. Academic press, New York, 1970

3. Edelman, G.M., U. Rutishauser and C.F. Millette. Cell fractionation and arrangement on fibers, beads, and surfaces. Proc. Nat. Acad. Sci. USA 68, 2153-2157, 1971

4. Hanjan, S.N.S. and G.P. Talwar. The selective action of poly AU on the electrophoretic mobility and surface charge of a subpopulation of B cells. J. Immunol. 114, 55-58, 1975

5. INOOKA, S. The adsorption of suspended MH129F cells to DEAE-Sephadex particles. Tohoku. J. Agr. Res. 20, 19-26, 1969

6. INOOKA, S. The adsorption of some kinds of cells to DEAE-Sephadex particles. Tohoku. J. Agr. Res. 20, 128-131, 1969 
7. Kedar, E., M. Ortiz de Landazuri and B. Bonavida. Cellular immunoadsorbents: A simplified to technique for separation of lymphoid cell population. J. Immunol. 112, 1231-1243, 1974

8. OKA, T. and Y.J. TOPPER. Insulin-sepharose and the dynamics of insulin action. Proc. Nat. Acad. Sci. USA 68, 2066-2068, 1971

9. Purbom, M.L., E.J. Ambrose and G. KLEIN. A correlation between electrical surface charge and some biological characteristics during the stepwise progression of a mouse sarcoma. Nature 181, 1586-1587, 1958

10. Scholssman, S.F. and L. Hudson. Specific purification of lymphocyte populations on a digestible immunoadsorbent. J. Immunol. 110, 313-315, 1973

11. Truffa-BACHI, P. and L. WofsY. Specific separation of cells on affinity columns. Proc. Nat. Acad. Sci. USA 66, 685-692, 1970

12. Wigzell, H. and B. Andersson. Cell separation on antigen-coated columns. Elimination of high rate antibody-forming cells and immunological memory cells. J. Exp. Med. 129, 23-36, 1969

(Received for publication, September 26, 1978) 